\title{
Application of ergonomics principles in un- derground mines through the Occupational Safety and Health Management System - OSHMS OHSAS 18.001:2007
}

\author{
Agnaldo Fernando Vieira de Arruda, ${ }^{\mathrm{a},}$, Leila Maral Gontijo ${ }^{\mathrm{b}}$ \\ ${ }^{a}$ Federal Institute of Goiás - IFG, Goiânia-GO, Brazil \\ ${ }^{b}$ PPGEP Federal University of Santa Catarina - UFSC, Florianopolis- SC, Brazil
}

\begin{abstract}
The underground mining activity is regarded as one of the activities that cause most accidents, deaths and illnesses in the world, highlighting the coal mines. This study examined how ergonomics principles can help improve this environment, reduce the number of accidents and occupational diseases, train and empower workers and leaders and humanize the activities of the duty cycle of an underground mine. For this, it was developed a conceptual model of safety managing and health at work for the underground mining through the incorporation of ergonomics principles in the Occupational Safety and Health Management System and OHSAS 18001 (2007). The elaboration of the model was based on analysis of the environments and stages of work in underground mines and the PDCA cycle to ensure continuous improvement.
\end{abstract}

Keywords: Underground Mining, Occupational Safety and Health Management, Ergonomics Principles

\section{Introduction}

Every year, thousands of miners die in accidents in the underground mining. There are several causes for the occurrence of accidents, including releases of toxic gases, collapse of the mines openings, coal dust explosions, floods, or from mechanical errors by misuse or malfunction of the mine equipment (DHILLON, 2010).

Confirming the issue, ILO (2009) states millions of people work in mining activities in an informal way, without labor protection or health insurance, which contributes to rising rates of accidents in this sector. It also reports the working conditions in the mining sector are poor, for an industry that employs about $1 \%$ of the workforce in the world and that, however, records the amount of $8 \%$ of fatal accidents

Homer (2009) describes that according to the information from the State Administration of Work Safety (SAWS) People's Republic of China and the
China Labor Bulletin the deaths of workers in Chinese mines were 5,798 in 2000, 5,670 in 2001; 6,995 in 2002; 6,434 in 2003; 6,027 in 2004; 5,986 in 2005; 4,746 in 2006 and 1,066 deaths in the first quarter of 2007 .

Thus, the statements of the ILO (2009), Grayson et al. (2009), Homer (2009) and Dhillon (2010) and statistics consolidate the problems of work safety in the underground mining.

The work practices in the underground mining are changing and therefore the risk exposures for workers are also changing. Longer displacements, fatigue and overload, mental fatigue, intermittent heavy physical work, little variation of the task, sedentary work in fixed postures and vibration in the body, besides the problems with aging, all pose risks to health and safety of workers underground. However, these aspects are not yet recognized, as they should, by the mining companies as potential causes of poor health and safety in the mining

*Corresponding author. E-mail: afva@terra.com.br. 
industry (McPHEE, 2004; SCHUTTE, 2005, and PLAMODON et al. 2006).

Companies in the face of new challenges due to increased international competition should consider that the ergonomics actions in the concept and respective workplaces can support the productivity and quality, and promote the health of their workers. The management often focuses on productivity, quality and economic profit, while the issues of work environment, sometimes, tend to be neglected (TORNSTROM, 2008).

However, despite the emergence of proposals for improvements and changes to the underground mines in recent years, they are still not satisfactory, especially by the reports and statistics presented, where underground mining still figures among the activities that cause most accidents, deaths and occupational diseases in the world.

In this scenario, the questions of Raman (2005) are still relevant, in the following questions: Are we doing enough in the underground mine safety? If the answer is yes, why are the results not reflected in the statistics? What are the indicators we have to assure that what we are doing is not only suitable but also effective? Finally, what else can we do to implement the philosophy of continuous improvement, and learn from the experience of other high-risk industries?

\section{Method}

The conceptual model developed was structured through the incorporation of ergonomics principles in OSHMS OHSAS 18001 (2007), based on the investigations of the underground mines activities and environment and the relationship between ergonomics, underground mining and work safety. The characterization of the underground mine and the relationship of ergonomics to the workplace safety and underground mining are described below.

\subsection{Characterization of Underground Mine: Environment and Activities}

The underground mine covers the work undertaken within the earth, either mechanized or manual, characterized by the mandatory presence of the worker in the underground environment, in order to promote the opening of the mine and ore extraction.

In this context, Donoghue (2004) considers the underground mining as a hard occupation and prone to injuries and illnesses that require further analysis and assessments on issues such as noise-induced hearing loss, ergonomics, respiratory diseases, security system work and risk management.

The works in the underground mining operations have a basic cycle, which according to Hartman and Mutmansky (2002) and Hustrulid (2001) involve the steps of drilling, disassemble, scaling, loading and transportation of the dismantled material, containment of the ceiling and walls of mine and finally the crew of itself with water, energy, compressed air and ventilation. In this context, one can represent the duty cycle of an underground mine through the steps in Figure 1.

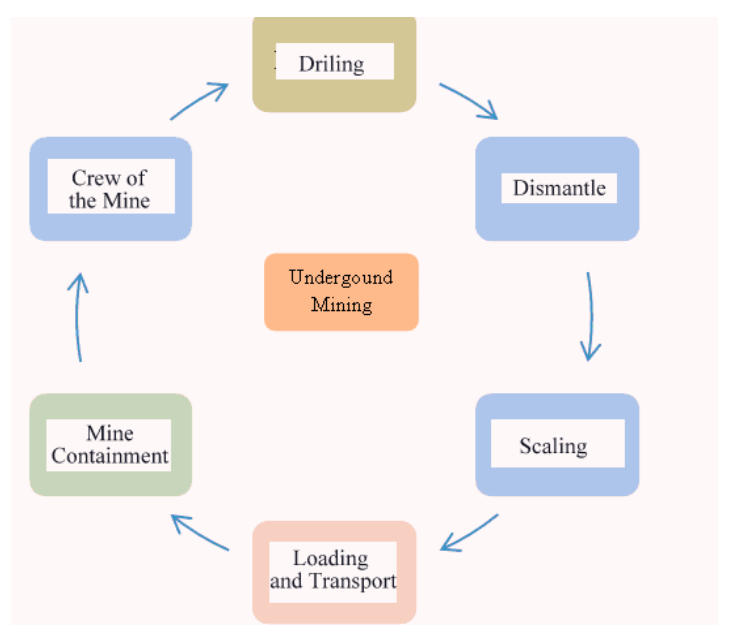

Figure 1 - Duty Cycle Stages of the Underground Mine

In the stage of drilling the rock drills are used manually or assembled on equipment, known as jumbo. The holes and the explosive charges follow a project called the fire plan, which according to Roy (2005) is the scaling of the number and location of holes in the mine, and their explosive charges and sequence of initiation of collapse.

The rock drilling activity requires: physical effort of the worker to assemble and dismantle the local infrastructure and operate the manual drilling and on equipment; standing posture during the execution of work, mental burden of perception, attention, knowledge and quick decisions to position and make the holes in the rock and see quarry buffer which may collapse.

In scaling stage the operation sums up to knock down the quarry buffer on the ceiling and walls of the mine, which can be done either manually or mechanically with the aid of equipment called scaler. 
Almeida (2004), Faria (2008) and Duzgun and Einstein (2004) consider this stage the toughest, the most dangerous and cause of major accidents

The manual activity of scaling demands a high physical effort to handle the lever and drop the blocks, along with a high upper limb posture for long periods. It is also required to have a perception of the underground environment and the right decisions through the high risk of accident presented by blocks of rock collapse of the ceiling and walls of the mine.

According to Tatiya (2005) the production cycle of an underground mine is completed with the altogether stages of loading and transport, carried out by loaders and lowered trucks. At this stage the dismantled material at front work of the mine is loaded and transported either by truck or by its own loaders.

In this context Foster and Burton (2006), Eger et al. (2004) and Godwin et al. (2007) comment on the position and visibility of operators of LHD loaders (Load Dump Haulp) used in underground mines describing the difficulties operators have to see people, objects or hazards around the machine, due to the blind spots and reduced line of sight in the underground environment.

Attentive and perceptual issues in these stages are essential to operate LHD loaders and drive lowered trucks due to the physical arrangements of equipment, by confinement and visibility of the environment.

The ceiling and walls support of the mine is realized through the rock mass containments with tether anchorage, canvas, wood crankshaft or shoring aiming to improve the conditions and the work environment (BROWN AND BRADY, 2004).

The activities of rock excavation underground promote a structural imbalance in rock mass, which seeks to find a new equilibrium, producing for this: moving of block in plans of geological discontinuities; deformation and tights on the roofs and sides of the excavated area; peeling of roof and side (quarry buffer); mechanical breakdown of roofs and sides of the excavation (TROTTER; KOPESCHNY, 1997).

This stage requires a physical and mental burden, through efforts and postures to make holes and placement of contain artifacts, along with the widespread perception, attention and quick decision to perform the containments of the ceiling and walls, which are considered as local high risk of rock blocks collapse.

After holding the ceiling and walls of the mine, it is held the crew of the front work, which sums up to the networks assemble: energy, water, compressed air, and ventilation needed for further work. These works are similar in terms of physical and mental demand for drilling rock and containment of the mine.

\subsection{Ergonomics, Work Safety and Risk Prevention}

According to Niu (2009), ergonomics has been an important part in safety of work and it is considered a field that integrates knowledge from the human science to answer the needs of jobs, systems, products and environments. The author also stresses that the ergonomics goal is especially to optimize the comfort of the worker as well as his health, safety and efficiency.

The application of ergonomics principles had proven success in improving performance, productivity, competitiveness, safety and health in most professional industries. It can also be argued that, throughout history, both practical and scientific research and applications of ergonomics have had a beneficial impact on health, safety and welfare of human society (Smith, 2009).

According to Falzon (2007), the specificity of ergonomics is the tension between its two goals; one is centered into the organization that can be seized under different dimensions: efficiency, productivity, reliability and quality, and the other one is peopleoriented and it is concerned to safety, health, comfort and satisfaction.

In the descriptions based on Niu (2009), Smith (2009) and Falzon (2007) the approach to ergonomics is made of a wide way within the organization, trying to relate the issues of ergonomics with the worker in a systemic manner, making clear the relationship with job security and opportunities for improving working environments and processes.

In this sense, EWA is important to the safety and risk assessment, because it reflects the reality of work, where, according to Vidal (2003), the ergonomics analysis is quantitative and qualitative which allows the description and interpretation of what happens in the reality of the focused activity.

The list of risks with EWA is well characterized by Falzon (2007), when he describes that for the conditions of exposure to risks that arise through the activity of work to be shown, it is necessary to mobilize EWA.

Depending on the methodology of EWA, it is clear that in making the diagnosis, the chances of preventing occupational health risks become greater, due to the work environment has gone through a 
thorough analysis of its physical, cognitive and organizational characteristics (ARRUDA et al., 2007).

In Maggi (2006) and Daniellou's view (2001), the guidelines of the European Community put the work analysis in a mandatory and prior form, as a way to prevent and avoid risks in the workplace.

It is in this precautionary context that EWA will act in the proposed conceptual model.

\subsection{The Ergonomics Relationship with the Underground Mining Activities}

Schutte (2005) describes that ergonomics is applied in a limited scale in the mining industry of South Africa; despite the fact the application of ergonomics principles can make significant contributions to risk management and occupational health and safety.

McPhee (2009) points out that Australia has made steady progress in the application of ergonomics in mining over the past 10 years. However, he points out there is still a lack of understanding about the contribution of ergonomics in organizational concept and management. To avoid these conditions, it is necessary the ergonomics to evolve and become more integrated into the overall management of systems safety.

In this context, James (2009) presents the following considerations about the involvement of ergonomics in the work of the underground mining:

- Monitoring the performance of mining projects in the areas of ergonomics and reducing security risks has been unsatisfactory, and efforts are ineffective;

- The lack of enforcement of basic safety and ergonomics principles remains worrying;

- The workplace is still far from ideal, with many cases of poor work conditions;

- While the mining industry appears to be committed to alleviating many of these problems, there is still much work to be done to implement and evaluate the safety and ergonomics;

- Security is generally regarded as an important project evaluator, but the basic ergonomics is applied only to a very limited extent in the mining area;

- One of the major obstacle has been the lack of structure and coordination of efforts to implement the ergonomics and as a result, no strategy for the implementation of programs has been implemented in the mines;

- The application of ergonomics principles can play an important role in reducing workplace hazards and improve the design of work which will benefit workers of all ages and experience levels.

Mayton et al. (2003) and Kittusamy (2005) describe the equipment of cargo and transport in the underground mines expose individuals to the whole body vibration. Despite the exposure to mechanical shocks affecting the health, safety and comfort of the worker as well as his efficiency and performance, the designs of seats were not priority in the projects of the vehicles for many years.

In approaching of the procedures for manual handling of loads and materials in the mines, Stewart et al. (2005) and Limerick et al. (2007) comment the manipulation of materials in the underground mine remains the category with the greatest potential for accidents and injuries, and mechanization and training activity of the worker are two methods that can help prevent these events.

The fatigue and attentive issues in underground workings are observed in Donoghue's work (2004), where he says that most underground mines operates 24 hours a day, 7 days a week, in shifts, the fatigue in relation to the shifts has been the subject of considerable research in mining, because they create deficiencies in sleeping, causing disturbances in the performance of cognitive and motor system, especially among drivers.

In this context, Ferguson et al. (2010) describe the amount of sleep obtained between work shifts is influenced by many factors, including the duration of work and rest, the calendar period of relative rest to the endogenous circadian cycle and personal choices on the use of working time.

\section{Results}

The conceptual model presented below was developed based on the investigations of the underground mines environment and ergonomics principles, and has five items, where the former refers to policies of OSH and the others refer to the stages of planning, implementation, verification and analysis, as shown in Figure 2. 


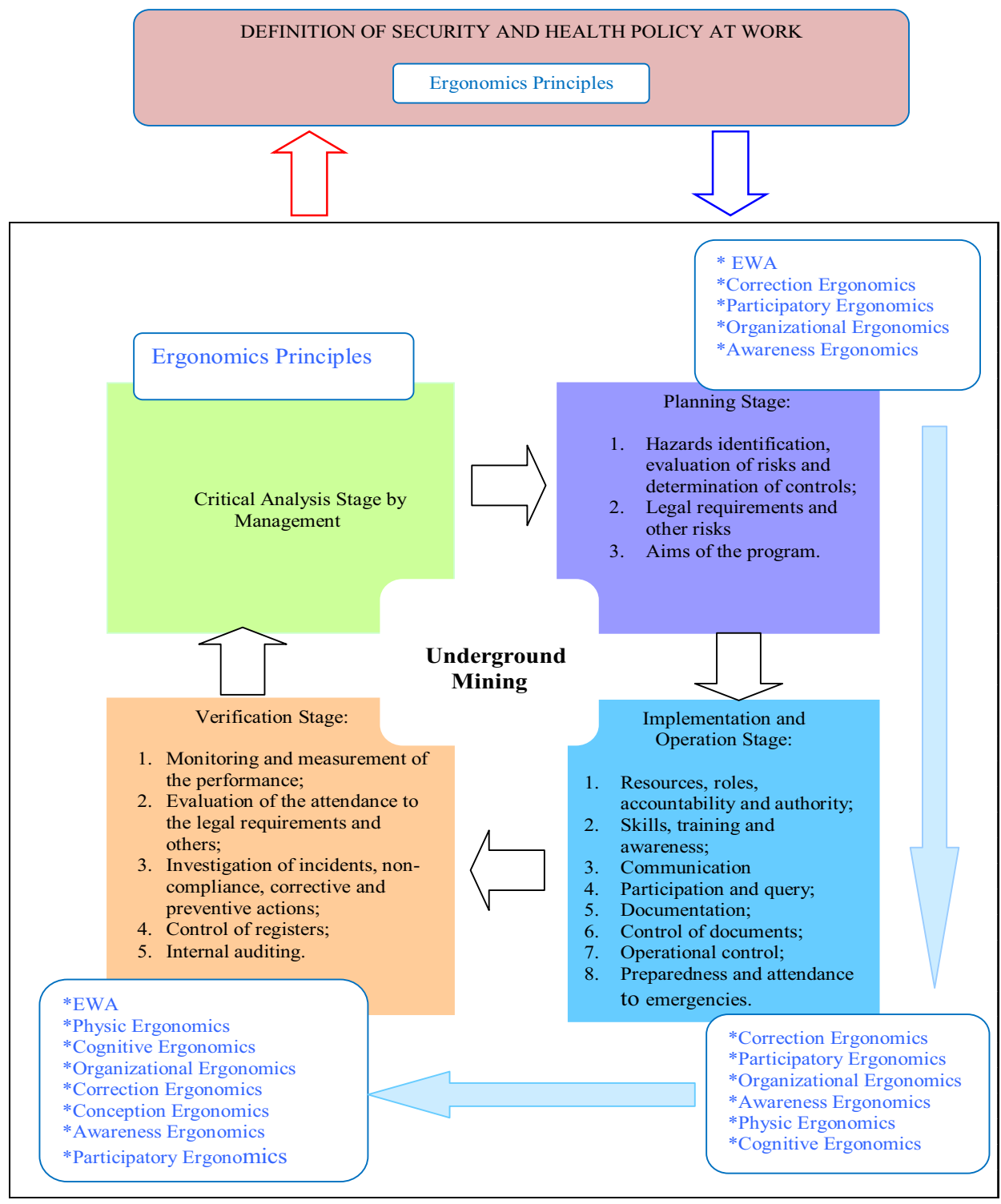

Figure 2 - Conceptual Model of OSHM to Underground Mining (Adapted from OHSAS 18.001(2007))

\subsection{Definition of the OSH Policy}

The organization's top management must define and authorize the OSH policy of underground mine and ensure that, within the defined scope of its OHSMS, the politics, among other aspects, is appropriate to the nature and scale of the risks of the underground mine, and presents the ergonomics principles included in their organizational culture and $\mathrm{OSH}$.

\subsection{Planning Stage}

At this stage of the model it will be established objectives and processes necessary to achieve the results of environmental improvement and reduction of the underground mine accidents, according to the OHS defined policy, through the following: hazard identification, risk assessment and determination controls, legal and other requirements, objectives and programs. 
The methodology the organization must used in order to hazard identification and risk assessment in the underground mine will be the Ergonomics Work Analysis - EWA - to be proactive and provide subsidies for identifying, prioritizing the documentation of the risks as well as for the application of controls, as it is suitable.

To ensure the goals of the underground mine $\mathrm{OSH}$ will be achieved, the organization must establish programs based on the ergonomics of awareness and participation, and organizational ergonomics.

Programs assembled with the ergonomics of awareness, the workers will be skilled and trained to identify and solve security issues and health problems at work in the underground mine.

In the programs assembled with organizational ergonomics principles the following precepts will be used: system optimization of the underground mine; the organization of the work cycle in the underground mine; quality management in the underground mine; and the management of resources.

\subsection{Implementation and Operational Stage}

This stage will be responsible for doing what was planned and implement the processes through the following: resources, roles, responsibility, accountability and authority, competence, training and awareness, communication, participation and consultation, documentation, document and operating controls, and preparedness and response to emergencies.

In relation to competence and training the organization must identify the needs of training through EWA, the OSH risks associated with the underground mine and its OSHMS.

The competence of workers in underground mines should be ensured through training and awareness that must be performed with the support of ergonomics awareness and participatory, as well as physical and cognitive ergonomics.

To develop the item documentation, the organization should consider the need for a document management system, which should be aided by the principles of organizational ergonomics, specifically those related to optimization of organizational structure and processes.

The organization must determine those operations and activities that are associated with the dangers of the underground mine and identified by EWA, where the implementation of controls is necessary to manage the risks of the underground mine.
For operations and activities of the underground mine, the organization must implement and maintain operational controls, once it is applicable to the stages and activities of the duty cycle of the underground mine, as defined by EWA, and approaches to physical and cognitive ergonomics.

For emergency issues the organization must use the principles of cognitive and awareness ergonomics as well, to train workers in situations of high stress and mental burden, to take decisions in emergencies such as: fire, explosion, flood, landslide and other fatal accidents within the underground mine.

\subsection{Verification Stage}

In this stage it will be verified whether the safety and ergonomics actions happened as they were planned. It will be responsible for monitoring and measuring the work processes of the underground mine in relation to OSH policy and objectives, legal requirements and results reporting. This check will be made through the following steps: monitoring and performance measurement, evaluation of care and other legal requirements, incident investigation, noncompliance, corrective and preventive actions, control and internal audit records.

The procedures to monitor the OSH performance should be made through EWA checking, along with the OSH approaches and ergonomics actions, involving physical, cognitive and organizational ergonomics principles, in places where there has been implementing controls.

The incident investigation must be based on conception, corrective, awareness and participatory ergonomic principles, beyond the diagnosis of EWA for the stages of the duty cycle of the underground mine.

The treatment of non-compliance through the implementation of corrective and preventive actions must be based on conception, corrective, awareness and participatory ergonomic principles, beyond the diagnosis of EWA for the stages of the duty cycle of the underground mine.

\subsection{Critical Analysis Stage by the High Management}

The organization must ensure that the review of senior management is also done based on ergonomics principles, especially on the analysis and diagnosis established by EWA on the stages of duty cycle of the underground mine. 


\section{Discussion}

The model proposes a way to evaluate the environments and stages of the duty cycle of the underground mines through the ergonomic principles, especially regarding to: ergonomic analysis of the environments, resolution of problems related to safety and health of the worker, verification of adopted solutions, capacity and training for identification, recognition and correction of risks, participation and employee involvement in solving $\mathrm{OSH}$ and ergonomic problems, and analysis of mental burden, stress and knowledge for decision making, which maintain a close relationship and a commitment to the improvement of the working environment and to the worker's safety and health.

The study results show that the performance of workers in the underground mines in unsuitable environments, dark, damp, with forced ventilation and dangers of explosions and landslides, and high mental workload and stress, contribute to the maintenance of high rates of accidents and deaths and that even existing OSHMS applications, development of standards and regulations for the underground mines, they still continue to show exceptionally high rates of accidents, including fatal ones, according to Dhillon (2010), Homer (2009), ILO (2009), and Grayson (2009).

\section{Conclusions}

This study was developed from the concerns about the environment and the level of accidents in the underground mines, and the inefficiency of OSHMS for this activity.

It was identified in the investigation that ergonomic principles are appropriate and relevant to the concerns of the study because they can contribute, through their incorporation into the OSHMS, to redeem the values of OSH and aspects of an underground mine.

Thus, one can consider that the incorporation of ergonomic principles in the organizational culture will play an important role in understanding the OSHM context of this organization.

The model is shown as a valid tool for identifying risks and hazards through the EWA, showing consistency in the explanation of the results against organizational dilemmas that the underground mines face.

The effective response from the underground mining companies in a matter of $\mathrm{OSH}$ will remain seriously affected while one continues to overlook: the underground working environment, the physical, cognitive and organizational work conditions in the underground mines, the management approaches of the OSHMS; the participation of the ergonomic principles in the environments and stages of the duty cycle in the underground mine; the allocation of responsibilities; training and qualification; employee involvement with the problems of mine; and the high management commitment.

The study estimates that the professional environment of underground mining companies to perform the work aiming to reduce the loss of lives, physical and mental injury is to happen by the adoption of an OSHMS, focusing on the ergonomics.

Thus, the expected result is that this adoption means a qualitative leap of organizational innovation, impacting on all levels, motivating the high management and employees around the risk prevention and reduction of accidents in the underground mines, with positive performance of the organization.

\section{References}

[1] Almeida, Ildeberto Muniz. A gestão cognitiva da atividade e a análise de acidente do trabalho. Revista Brasileira de Medicina do Trabalho, Belo Horizonte, Vol. 2 No 4 p. $275-282$, out-dez, 2004.

[2] Arruda, Agnaldo Fernando Vieira de et al.. A análise ergonômica do trabalho como medida de prevenção da segurança e saúde do trabalho Anais do XXVII Encontro Nacional de Engenharia de Produção - ENEGEP. Foz de Iguaçu-PR, out., 2007.

[3] Brown, Edwin T.; BRADY, Barry H. G. Rock mechanics: for underground mining. Third Edition - London: Springer, 2004.

[4] Daniellou, F. (Coord.). A Ergonomia em busca de seus nprincipios. Debates Epistemológicos. São Paulo: Edgard Blucher, 2004.

[5] Dhillon, Balbir S. Mine Safety: A Modern Approach. London: Editor Springer, 2010.

[6] Donogue, A. M. Occupational health hazards in mining: an overview. Occupational Medicine, Austrália, Vol. 54, n. 5, p. 283-289, abr 2004. Disponível em http://www.occmed.oxfordjournal.org/cgj/abstract/54/5/297. Acesso em: 28 de mar. 2008.

[7] Duzgun, H. S. B.; Einstein, H. H. Assessment and management of roof falls risks in underground coal mines. Safety Science, Vol. 42, n.1, p.23-41, jun. 2004. Disponível em http://www.sciencedirect.com/science. Acesso em: 02 de ami. 2010.

[8] Eger, T.; Salmoni, A. \& Whissel, R. Factors influencing loadhaul-dump operator line of sight in underground mining. Applied Ergonomics, Vol. 35, n. 2, mar 2004, p. 93-103. Disponível em http://www.sciencedirect.com/science. Acesso em: 28 de mar. 2008. 
[9] FALZON, Piérre (editor). Ergonomia.São Paulo: Editora Blucher, 2007.

[10]FARIA, Mario Parreiras de. Fatores Intervenientes na Segurança do Trabalho de Abatimento Mecanizado de Rochas Instáveis em uma Mina Subterrânea de Ouro. Belo Horizonte, 2008. 66p. Dissertação (Mestrado em Saúde Publica) Programa de Pós - Graduação em Saúde Pública, Universidade Federal de Minas Gerais.

[11]FERGUSON, Sally A. et al.. Sleep in a live-in mining operation: The influence of start times and restricted non-work activities. Applied Ergonomics, Vol. 42, n. 1, dez. 2010, p. 7179. Disponível em http://www.sciencedirect.com/science. Acesso em: 03 de jan. 2010 .

[12]FOSTER P. J., BURTON A. Modelling potential sightline improvements to underground mining vehicles using virtual reality. Mining Technology, Vol. 15 n. 3, mai. 2006, p. 85-900 Disponível em http://www.sciencedirect.com/science. Acesso em: 03 de jan. 2010

[13] GODWIN, A. et al.. Postural implications of obtaining lineof-sight for seated operators of underground mining loadhaul-dump vehicles. Ergonomics, Vol 50, n. 2, fev. 2007, p. 192-2007. Disponível em http://www.sciencedirect.com/science. Acesso em: 10 de jul. 2010.

[14]GRAYSON, R. Larry et al.. Pilot sample risk analysis for underground coal mine fires and explosions using MSHA citation data. Safety Science, Vol. 47, n. 10, p. 1371-1378, dez. 2009. Disponível em http://www.sciencedirect.com/science. Acesso em: 10 de jul.2010.

[15]HARTMAN, Howard L.; MUTMANSKY, Jan M. Introductory mining engineering. Second Edition - New Jersey: John Wiley and Sons, 2002.

[16] HOMER, Andrew W. Coal Mine Safety Regulation in China and the USA. Journal of Contemporary Asia. Vol. 39, n. 3, ago. 2009, p. 424-439. Disponível em: http://www.tandf.co.uk/journals/rjoc. Acesso em: 10 de jul. 2010.

[17]HUSTRULID, William A.. Underground mining methods: engineering fundamentals and international case studies. Littleton: SME, 200

[18] AMES, Jonathan P. Tracking project ergonomics and safety performance in the South African mining industry. Anais do XVII World Congress on Ergonomics - IEA. Beijing, ago., 2009.

[19]JOY, J.. Occupational safety risk management in Australian mining. Occupational Medicine, Austrália, v.54, n. 5, p. 311315, abr 2004. Disponível em http://www.occmed.oxfordjournal.org/cgj/abstract/54/5/297. Acesso em: 24 de abr. 2006.

[20]KITTUSAMY, N. Kumar, et al.. A Systematic Comparison of Different Seats on Shuttle Cars Used in Undergroud Coal Mines. NIOSH - National Institute for Occupational Safety and Health, Sponkane, U.S., ago 2005, p. 2025-2032. Disponível

http://www.cdc.gov/niosh/mining/pubs/pubreference/scods.ht m. Acesso em: 26 de abr. 2006.

[21]LIMERICK, Robin Burgess et al.. Implementation of the Participative Ergonomics for Manual tasks (PErforM) programme at four Australian underground coal mines. International Journal of Industrial Ergonomics, Vol 37, n. 2, fev. 2007, p. 145-155. Disponível em http://www.elsevier.com/locate/ergon. Acesso em: 10 de jul. 2010

[22]MAGGI, Bruno. Do agir organizacional: um ponto de vista sobre o trabalho, o bem estar, a aprendizagem. São Paulo: Edgard Blucher, 2006.
[23]MAYTON, Alan, et al.. Ergonomics and existing seat designs compared on underground mine haulage vehicles. NIOSH National Institute for Occupational Safety and Health, Pittsburgh, U.S., out 2003, p. 1256-1260. Disponível em http://www.cdc.gov/niosh/mining/pubs/pubreference/eaesd.ht m. Acesso em: 26 de abr. 2006.

[24] McPHEE, B.. Ergonomics in mining. Occupational Medicine, Austrália, v.54, n. 5, p. 297-303, abr 2004. Disponível em http://www.occmed.oxfordjournal.org/cgj/abstract. Acesso em: 24 de abr. 2006.

[25]McPHEE, B.. Promoting occupational ergonomics in mining in Australia. Anais do XVII World Congress on Ergonomics IEA. Beijing, ago., 2009.

[26]NIU, Shengli. Ergonomics and Occupational Safety and Health: An ILO Perspective. Anais do XVII World Congress on Ergonomics - IEA. Beijing, ago., 2009

[27] OHSAS 18.001. Occupations Health and Safety Assessment Series. British Standards Institution (BSI), Grã-Bretanha, 2007.

[28]OIT. Anuário Estatístico da Organização Internacional do Trabalho: 2009. Genebra, 2009. Disponível em: http://www.oit.org.br/info/estat.php. Acesso em: 20 de ago. 2010.

[29]PLAMODON, André et al.. Manual materials handling in mining: The effect of rod heights and foot positions when lifting "in-the-hole" drill rods. Applied Ergonomics, Vol. 37, n. 6, nov. 2006, p. 709-718. Disponível em http://www.sciencedirect.com/science. Acesso em: 28 de mar. 2008.

[30]RAMAN, Raghu. Underground mine safety - are we going enough? AUCTA-Australian Underground and Construction and Tunneling Association, Sidney, AU, 2005. Disponível em http://www.aucta.com.au/techpaper. Acesso em: 4 de nov. 2007

[31]ROY, Pjjush Pal. Rock Blasting: effects and operations. New Jersey: Balkema, 2005

[32] SCHUTTE, P. C. Ergonomics in the South African mining industry. Journal of The South African Institute of Mining and Metallurgy. Vol. 105, n. 6, jul 2005, p. 369-372. Disponível em http://www.scopus.com/scopus/. Acesso em 29 de mar 2008.

[33] SMITH, Thomas J. Certification of Professional Ergonomists - Who, Why and How. Anais do XVII World Congress on Ergonomics - IEA. Beijing, ago., 2009.

[34]STEWART, Bill M., et al.. Solutions to prevent materialshanling injuries in underground coal mines. NIOSH - National Institute for Occupational Safety and Health, Spokane, U.S., mar $2005 . \quad$ Disponível em http://www.cdc.gov/niosh/mining/pubs/pubreference. Acesso em: 26 de abr. 2006.

[35] TATIYA, Ratan Raj. Surface and underground excavations: methods, techniques and equipment. Michigan: A. A. Balkema, 2005.

[36] TORNSTROM, Linda et al.. A corporate workplace model for ergonomics assessments and improvements. Applied Ergonomics, Vol. 39, n. 2, mar. 2008, p. 219-228. Disponível em http://www.elsevier.com/locate/apergo. Acesso em: $30 \mathrm{de}$ nov. 2009.

[37] TROTTER, D. A., KOPESCHNY, F. V. Cap lamp improvement in canadian mines. Applied Occupational Environmental Hygiene, v.12, n.12, p. 859-863, 1997. Disponivel em http://www.cdc.gov/NIOSH/Mining/pubs/pdfs/vpfia.pdf. Acesso em: 15 de jul.2010.

[38] VIDAL, M. C. Ergonomia na empresa, útil, prática e aplicada. $2^{\mathrm{a}}$ ed. Rio de Janeiro: Editora CVC, 2003. 